\title{
Watermills - a Forgotten River Valley Heritage - selected examples from the Silesian voivodeship, Poland
}

\author{
Maria Fajer
}

Department of Environment Reconstruction, Faculty of Earth Sciences, University of Silesia, Będzińska Str. 60, 41-200 Sosnowiec, Poland

E-mail address: maria.fajer@us.edu.pl

\section{ABSTRACT}

This study is an attempt to describe the current condition of the watermills situated in the river valleys of the Silesian voivodeship. Changes in the number and distribution of mills from the late $18^{\text {th }}$ century until the $20^{\text {th }}$ century have been presented (as exemplified by the Liswarta River basin in the northern part of the voivodeship). Watermills have been discussed both as industrial monuments that document the history of the milling industry and as tourist attractions. Currently, working mills that serve the local population in rural areas are a rarity, and working watermills are unique sites that should be protected as industrial monuments that constitute an important part of our cultural heritage. They are among those industrial monuments that are particularly vulnerable to destruction. Such mills increasingly attract the interest of industrial tourism promoters. Activities aimed at promoting watermills as cultural heritage sites and leading to their protection and preservation as part of the river valley landscape have also been discussed. In the Silesian voivodeship, there are many watermills that deserve attention; some of these are listed in the register of monuments maintained by the National Heritage Board of Poland. Unfortunately, most disused mills are falling into disrepair and are slowly disappearing; only a few have been preserved in good condition. Many of these have long histories and they are also situated in areas attractive for tourists. There is no doubt that watermills should be preserved. Their inclusion in open-air museums is not the only solution - any form of protection in situ by putting them to different uses is also valuable. Changing the function of a mill to serve as a hotel, restaurant, cultural centre, etc. makes it possible to maintain these sites as parts of river valley landscapes.

KEY WORDS: cultural heritage, tourism, industrial monuments, protection of watermills

\section{Introduction}

For several centuries, watermills used to be a characteristic element of river valley landscapes. From the Middle Ages, the water wheel was used to produce the mechanical energy required to power cereal mills and later also iron smithies. Other plants, e.g. fulleries and sawmills, were also often situated close to watermills. The water wheel was later superseded by the water turbine, which became popular in the 1920s and 1930s. Milling with the use of hydro power was one of the oldest forms of food processing in rural areas.

In the age when flowing water provided the most important (and fairly reliable) source of energy, river valleys played the role of axes along which various branches of industry developed. In river valleys throughout Poland, plants can still be found that used hydro power; many of these are industrial monuments nowadays. This group also includes watermills, which not only testifies to the use of rivers as sources of power and showcases ancient technology but also gives insights into the life of the people who lived around them. Most extant sites were constructed in the $19^{\text {th }}$ century, or at the beginning of the $20^{\text {th }}$ century. Today, they are mostly disused and falling into disrepair; only a handful of upgraded ones continue to operate. These sites are present throughout the Silesian voivodeship, but they are usually treated marginally in various studies of the area.

As industrial monuments, such mills increasingly attract the interest of industrial tourism promoters. Although owing to the peculiar characteristics of the Silesia region, the most popular industrial 
tourist attractions tend to be coal mines and steel mills, large hydro-engineering structures and railway facilities, more attention should be paid to the somewhat forgotten watermills. Abandoned mills are falling into disrepair; in many cases, only ruins of buildings and weirs are left, and sometimes the only evidence that a mill used to operate at the site are morphological traces showing the former course of a dyke or mill race.

\section{Materials and methods}

The conditions of mills in selected areas of the Silesian voivodeship have been analysed. Basins of the Liswarta and upper Pilica Rivers (Fig. 1A) have been examined in detail. In the upper Liswarta River basin, comparative analyses of maps from different periods (from the $18^{\text {th }}$ to the $20^{\text {th }}$ century) have been conducted to determine changes in the distribution of mills. In the study, the register of monuments maintained by the National Heritage Board of Poland and historical sources (literature, photographs and plans) as well as the information included on the websites of museums and municipal offices (lists of monuments) were used. Field observations were also conducted, during which the condition of watermills and hydro-engineering structures was examined.

\section{Watermills in river valley landscapes}

Watermills appeared in Poland in the late $11^{\text {th }}$ and early $12^{\text {th }}$ centuries, and became widespread in the $13^{\text {th }}$ century (Baranowski, 1977). From that time, they formed part of the landscape of almost every village and town for several centuries. Initially, watermills with undershot wheels were constructed, which did not require water to be banked up. In the second half of the $15^{\text {th }}$ century, mills with (three times more efficient) overshot wheels became widespread; races or flumes were then used to guide water to such wheels. They, however, required the water to be banked up fairly high. In the mid-18th century, mills equipped with breastshot wheels began to be constructed (BARANOWSKI, 1977).

The distribution of mills depended on the existing river network, population density and property ownership. In the mid-14th century, there was on average one mill per 1.5 villages in some areas of Lower Silesia (BARANOWSKI, 1977). Between the $16^{\text {th }}$ and $18^{\text {th }}$ centuries, watermills were already a common feature of the landscape in the territories that are now Poland. Not only did the number of mills grow but the technical standards of milling improved as well. The engineers gained the ability to bank up water and bring it to the wheel and also to construct various hydraulic structures. Watermills with overshot wheels, multiple wheels and wheels whose position could be varied depending on the water stage became widespread. Mills with multiple wheels were also present in the territories that now belong to the Silesian voivodeship (e.g. in Krzepice, Kłobuck and Częstochowa) (SŁOWNIK HISTORYCZNO-GEOGRAFICZNY). Dams or small ponds were constructed for the purposes of operating watermills. Milling became one of the most important branches of production in the Polish economy.

In addition to cereal mills, iron smithies also used water wheels as sources of power. From the $14^{\text {th }} / 15^{\text {th }}$ century onwards, such smithies operated on the River Pankówka (Kuźnica Stara - "Old Smithy") and later also on the Liswarta (Kuźnica Nowa - "New Smithy"), Warta, Czarna Przemsza, Biała Przemsza and Mała Panew rivers (ZIĘTARA, 1954). Some cereal mills were accompanied by specialist production plants, e.g. oil presses, fulleries or sawmills, which subsequently either became separate branches of industry or lost their significance (fulleries).

In the territories that are now Poland, ca. 17,000 mills operated in the late $18^{\text {th }}$ century, of which ca. 10,500 were watermills. Approximately $82.4 \%$ of mills were located in rural areas and ca. $17.6 \%$ in cities. On average, one mill served an area of about $18 \mathrm{~km}^{2}$ and 500 inhabitants. In the districts that are now included in the Silesian voivodeship (e.g. Gliwice, Lubliniec, Pszczyna, Bytom) watermills clearly prevailed with windmills accounting for less than 2\% (BARANOWSKI, 1977).

In the $19^{\text {th }}$ century, small mills began to be replaced by larger and more efficient plants; as a result, the number of watermills decreased and they became more concentrated. In the 1920s and 1930s, water wheels were increasingly superseded by water turbines, which were 25$40 \%$ more efficient (Baranowski, 1977). Steam and combustion engines and electric motors also started to be used to drive mills - initially as auxiliary sources of energy, and subsequently mills emerged that were entirely driven by engines or motors and no longer had to be built on rivers. Technological advances were also apparent with respect to the machinery inside millstones were replaced with roller mills, and modern cleaning and sieving equipment was installed (BARTYŚ, 1978). 


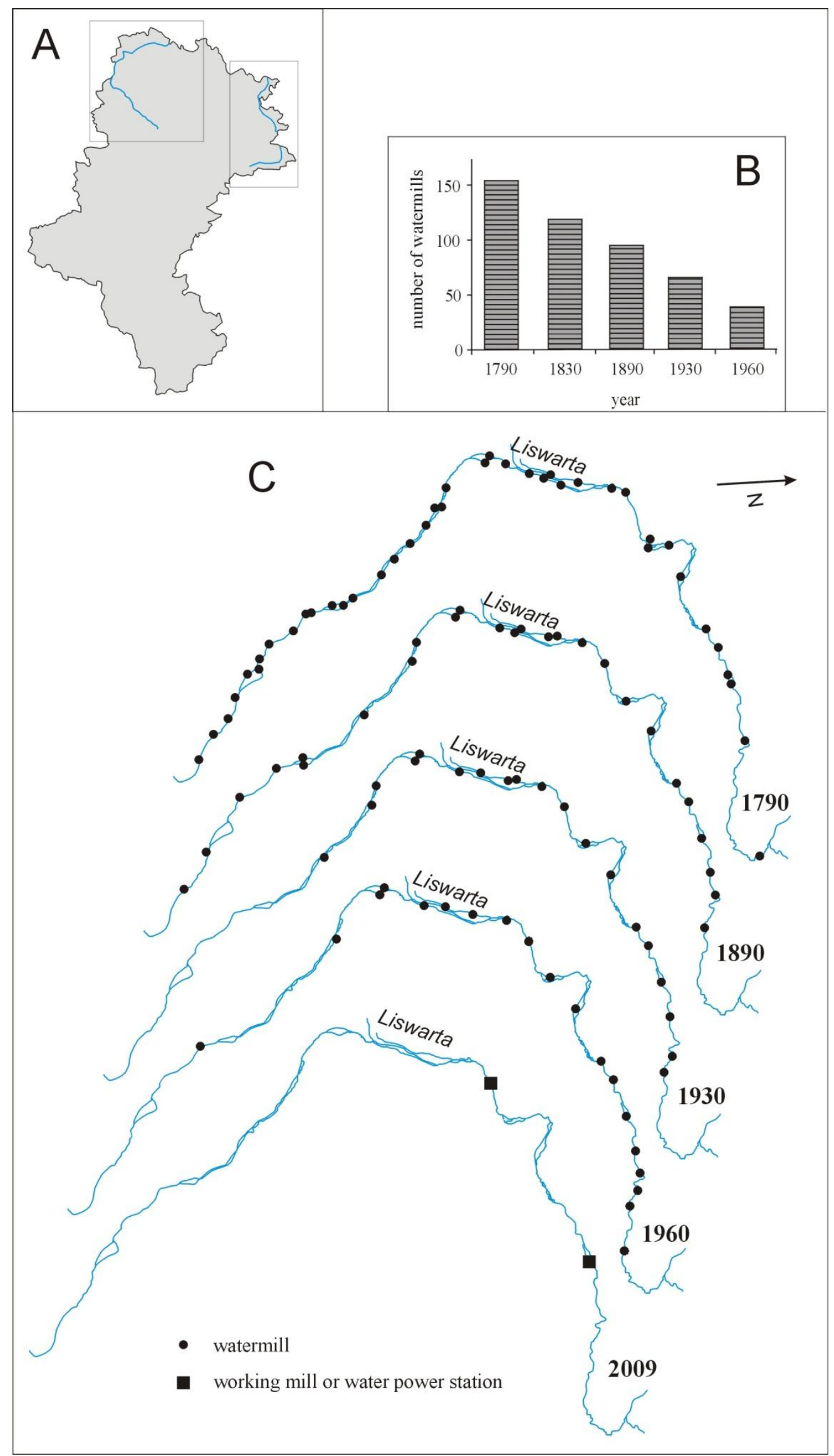

Fig. 1. Changes in the number of watermills in the Liswarta River basin from the $18^{\text {th }}$ to the $20^{\text {th }}$ centuries A - location of the areas analysed within the Silesian voivodeship, B - decline in the number of watermills in the Liswarta River basin from 1790 to 1960 (according to Fajer, 2011), C - changes in the distribution of watermills on the Liswarta River from 1790 to 2009 (according to Fajer, Waga, 2010) 
For several centuries, watermills used to be small wooden structures. At the end of the $19^{\text {th }}$ and at the beginning of the $20^{\text {th }}$ century, multistorey mills began to be constructed that were entirely built of brick or with wooden upper storeys (BARANOWSKI, 1977; BALIŃSKA \& BALIŃSKI, 2003).

Technological changes in the milling industry resulted in the increased role of large commercial and industrial mills (BARTYŚ, 1978), with which the often obsolete mills that served the local population could not compete. In 1935, there were 16,158 mills in Poland, of which 14,917 were mills that served the local population (including 6,000 watermills) and 1,241 were commercial and industrial mills (BALIŃSKA \& BALIŃSKI, 2003).

After World War II, the number of watermills decreased significantly. Water turbines and internal combustion engines were gradually replaced with electric motors. Some mills retained two sources of energy - water and an engine/motor. The regulation of rivers and irrigation works conducted from the 1950 s to the 1980 s caused some mills to be cut off from water, which had provided a cheap source of energy. Some races, dams and mill ponds were filled in at the time, which significantly affected local water relations.

Studies conducted in the northern part of the Silesian voivodeship, in the Liswarta River basin, show that from the late $18^{\text {th }}$ century until the mid-20th century the number of mills decreased to less than a third of the original figure (FAJER, 2011; Fig. 1B). A similar trend towards the disappearance of mills was observed throughout Poland (BALIŃSKA \& BALIŃSKI, 2003; PODGÓRSKI, 2004, 2009; KUŹNICKI, 2009; KANIECKI \& BRYCHCY, 2010).

It is difficult to accurately determine the current number of watermills extant in the Silesian voivodeship, since no records of such sites are being kept. Most of them date from the late $19^{\text {th }}$ and the early $20^{\text {th }}$ centuries. Such mills were rebuilt and upgraded during their operation. Some older wooden structures from the $17^{\text {th }}$ and $18^{\text {th }}$ centuries were replaced by brick and wood or brick-only buildings and the water drive (water wheel or turbine) by electric motors (Table 1 ).

Many watermills (which used electric power in the last years of their operation) have been preserved in the northern and north-eastern part of the Silesian voivodeship - on the River Liswarta and its tributaries and in the upper River Pilica basin (Table 1). This was probably due, inter alia, to the agricultural character of these areas. In urban areas in the central part of the Silesian voivodeship, a few mills have been preserved, including those on the River Drama (between Tarnowskie Góry and Pyskowice) and in the River Przemsza basin (Dąbrowa Górnicza).

On the Liswarta and Pankówka Rivers, there are currently 13 mills and the remains of five further mills (ruins of buildings, traces of foundations or mill dams on the river). In addition, mills or their traces have been found on the other tributaries of the River Liswarta - on the Górnianka, Biała Oksza and Kocinka Rivers. In the upper River Pilica basin, nine extant mills, mostly wooden, have been found (Table 1).

Today, working mills that serve the local population in rural areas are a rarity, and mills that use hydro power are unique sites that should be protected as industrial monuments that constitute an important part of our cultural heritage. In addition, watermills, and particularly wooden ones, are major tourist attractions.

A watermill comprises not just the mill building itself but also their accompanying structures (facilities) as well as the entire infrastructure, i.e. race, weir, pond and dikes. These structures and facilities often have considerable aesthetic value and the picturesque landscape of the river valley further increases their attraction as tourist sites. As a result of the construction and operation of watermills, the landscape in their immediate vicinity changed and the so-called mill hamlet cultural landscape emerged, which is a harmonious type of landscape (PoDGóRSKI, 2001, 2009). In the River Liswarta basin area analysed, the most typical example of such a mill hamlet surrounded by woodland is Kluczno.

\section{Watermills in the Silesian voivodeship as industrial monuments and tourist attractions}

Measures aimed at the preservation and promotion of industrial monuments that are falling into disrepair as a result of the disappearance of certain industries or technologies are of interest to a growing number of people. Industrial sites have been included in tourist itineraries in Poland for quite a long time now. Industrial tourism is understood as recreation, education and active leisure organised in areas with present or past industrial activity (OSIECKI, 2005). Polish tourists are increasingly interested in visiting various regions of Poland and appreciate regional, including industrial, heritage. Numerous academic studies have also been devoted to tourism in industrial and post-industrial areas (BURZYŃSKI \& ŁABAJ, 2005; BURZYŃSKI ET AL., 2009; LAMPARSKA, 2013). Tourism related to industrial 
heritage, which dates back to the 1980s, has boomed in recent years.

Among the best examples of promotion of technological and industrial heritage is the Industrial Monuments Route of the Silesian voivodeship, which is included in the European Route of Industrial Heritage (ERIH). The Industrial Monuments Route, which opened in 2006, has become an important feature associated with the Silesian voivodeship alongside the Industriada festival, which has been held for several years and enjoys great popularity. From 2009 to 2013, the sites included in the Industrial Monuments
Route were visited by nearly 3 million tourists (http://www.zabytkitechniki.pl/Aktualnosci/). Currently, the route includes 36 sites, of which none are watermills.

Watermills are often a forgotten part of our cultural heritage and are also among those industrial monuments that are particularly vulnerable to destruction. They have become unnecessary and obsolete, and repairing their wooden structures is quite expensive and often not cost-effective. Many valuable sites have already disappeared, e.g. the $17^{\text {th-century wooden }}$ watermill in Turze near Racibórz.

Table 1. Watermills in the Liswarta and upper Pilica River basins - selected examples (source: own research based on online sources: http://www.nid.pl, http://www.polskaniezwykla.pl, http://www.zabytkitechniki.pl)

\begin{tabular}{|c|c|c|}
\hline Location & Year of construction & Description \\
\hline \multicolumn{3}{|r|}{ On the Liswarta and Pankówka Rivers } \\
\hline Kluczno & $\begin{array}{l}\text { ca. } 1830 \text {, altered in } \\
1927\end{array}$ & $\begin{array}{l}\text { Mill hamlet, wooden mill with preserved equipment and working milling } \\
\text { mechanism; disused, can be visited; located within the "Forests of the Upper } \\
\text { Liswarta" Landscape Park }\end{array}$ \\
\hline Ługi-Radły & $1930 \mathrm{~s}$ & $\begin{array}{l}\text { Brick two-storey mill (formerly wooden mill with a water wheel); mill with a } \\
\text { water turbine and electric motor; operated until the 1990s; now used as a } \\
\text { granary; in the 1960s the canal supplying water to the turbine was filled in as } \\
\text { a result of the regulation of the River Liswarta }\end{array}$ \\
\hline Kuźnica Nowa & Early $20^{\text {th }}$ century & Wooden, disused \\
\hline Kuźnica Stara (Fig. 2) & Early $20^{\text {th }}$ century & $\begin{array}{l}\text { Iron smithy in the } 18^{\text {th }} \text { and } 19^{\text {th }} \text { centuries; two-storey brick and wood } \\
\text { structure, equipment from the } 1920 \text { s and } 1930 \text { s; working mill }\end{array}$ \\
\hline Kostrzyna & 19th $/ 20^{\text {th }}$ century & Working three-storey brick mill \\
\hline Starokrzepice & 1909 & $\begin{array}{l}\text { Water turbine, currently electrified (the turbine drives an electric generator); } \\
\text { working mill }\end{array}$ \\
\hline Krzepice (Fig. 3) & 1876 & Brick and wood mill, water turbine, disused \\
\hline Danków & $19^{\text {th }}$ century? & Disused three-storey brick mill \\
\hline Troniny (Fig. 4) & 1901 & $\begin{array}{l}\text { Four-storey stone mill; formerly a wooden mill with a water wheel with a } \\
\text { diameter of more than } 3 \text { metres; water turbine since 1946; disused }\end{array}$ \\
\hline Rębielice Szlacheckie & $\begin{array}{l}\text { Already operating } \\
\text { in } 1827\end{array}$ & Change of function - small hydro power plant \\
\hline Krym (Fig. 5) & Early $20^{\text {th }}$ century & Wooden mill with equipment preserved, disused \\
\hline \multicolumn{3}{|r|}{ Upper Pilica River basin } \\
\hline Żarnowiec & Early $20^{\text {th }}$ century & $\begin{array}{l}\text { Wooden, lined with metal sheeting; equipped with a generator using a simple } \\
\text { water wheel; disused }\end{array}$ \\
\hline Łany Wielkie & Early $20^{\text {th }}$ century & $\begin{array}{l}\text { Mill farmstead, wooden mill in poor condition and with no milling equipment, } \\
\text { powered by a water turbine, disused }\end{array}$ \\
\hline Szczekociny & Early $20^{\text {th }}$ century & Working wooden mill that provides services for the local population \\
\hline Przyłęk & Early $20^{\text {th }}$ century & Wooden, disused \\
\hline Grabiec & Mid-19th century? & Wooden, powered by a water turbine, mill equipment preserved, disused \\
\hline Bonowice & 1886 & $\begin{array}{l}\text { With a 1920s water turbine and complete equipment dating from that period, } \\
\text { powered with an electric motor in the final period of its operation, disused }\end{array}$ \\
\hline Lelów & Late $19^{\text {th }}$ century? & $\begin{array}{l}\text { Wooden on a brick foundation, powered by a water turbine, disused } \\
\text { since } 1945 \text {, burned down in } 2014\end{array}$ \\
\hline Biała Wielka & 1935 & Brick and wood, three-storey, operated until 2008, disused \\
\hline Bogumiłek & 1934 & Three-storey wooden mill, water turbine, disused \\
\hline
\end{tabular}




\subsection{Watermills as industrial monuments}

The Silesian voivodeship boasts the greatest number of industrial monuments in Poland. According to the National Heritage Board of Poland, 192 industrial monuments are registered in the Silesian voivodeship (REJESTR ZABYTKóW, 2014). This group only includes six watermills, including two in the River Liswarta basin - in Stara Kuźnica on the River Pankówka (Fig. 2) and in Kluczno on the upper reach of the River Liswarta (Table 2). This is a small number given that there are about 1,700 registered historic water and engine/motorpowered mills in Poland (PASZKIEWICZ, 2005). It should be stressed that the number of historic watermills in the Silesian voivodeship quoted here does not include those sites included in municipal registers of monuments that are not included in the register of the National Heritage Board of Poland.

Table 2. Historic watermills in the Silesian voivodeship (own research on the basis of: Rejestr zabytków... and www.zabytkitechniki.pl/)

\begin{tabular}{|c|c|c|c|}
\hline Location & River & Construction date & Description \\
\hline \multicolumn{4}{|c|}{ Listed in the register of monuments of the National Heritage Board of Poland } \\
\hline Kluczno & Liswarta & $\begin{array}{l}\text { ca. } 1830 \text {, altered } \\
\text { in } 1927\end{array}$ & $\begin{array}{l}\text { Mill hamlet, wooden mill with preserved equipment and } \\
\text { working milling mechanism; disused, can be visited; } \\
\text { located within the "Forests of the Upper Liswarta" } \\
\text { Landscape Park }\end{array}$ \\
\hline Kuźnica Stara (Fig. 2) & Pankówka & Early $20^{\text {th }}$ century & $\begin{array}{l}\text { Brick and wood structure, iron smithy in the } 18^{\text {th }} \text { and } 19^{\text {th }} \\
\text { centuries; equipment from the } 1920 \text { s and } 1930 \text { s; working } \\
\text { mill }\end{array}$ \\
\hline Wiercica & Wiercica & $19^{\text {th }} / 20^{\text {th }}$ century & $\begin{array}{l}\text { Wooden mill with electric motor and production line } \\
\text { preserved }\end{array}$ \\
\hline $\begin{array}{l}\text { Dąbrowa Górnicza - } \\
\text { Ratanice }\end{array}$ & Czarna Przemsza & $18^{\text {th }}$ century & $\begin{array}{l}\text { Brick and wood, used until the mid-1960s, disused, in poor } \\
\text { condition }\end{array}$ \\
\hline Sławków & Biała Przemsza & 1820 & $\begin{array}{l}\text { Mill complex, old milling equipment preserved inside the } \\
\text { mill }\end{array}$ \\
\hline Rybarzowice & Żylica & 1866 & $\begin{array}{l}\text { Brick mill with a house attached, built in place of a wooden } \\
\text { watermill from the early } 17^{\text {th }} \text { century, disused since the } \\
\text { early } 1970 \text { s }\end{array}$ \\
\hline \multicolumn{4}{|c|}{ According to the International Centre for Documentation and Research on Industrial Heritage for Tourist Purposes in Zabrze } \\
\hline Tworków* & Białka & 1914 & $\begin{array}{l}\text { Mill farmstead, brick mill (built on the site of a wooden mill } \\
\text { from 1703), driven by a water turbine, now electrified. } \\
\text { Working mill, which produces flour using traditional } \\
\text { methods; demonstrations for visitors are offered, can be } \\
\text { visited }\end{array}$ \\
\hline Biała Wielka* & Białka Lelowska & 1935 & $\begin{array}{l}\text { Three-storey brick and wood mill, water turbine, operated } \\
\text { until 2008, disused }\end{array}$ \\
\hline
\end{tabular}

*An outstanding industrial and technology monument (not listed in the register of monuments of the National Heritage Board of Poland) - according to the list of additional monuments drawn up by the International Centre for Documentation and Research on Industrial Heritage for Tourist Purposes in Zabrze

Old watermills are on display at open-air museums throughout Poland (including the Kielce Village Museum in Tokarnia, the Museum of Rural Architecture in Opole, the Folk Architecture Museum in Sanok, the Museum of Agriculture in Ciechanowiec and the Ethnographic Museum in Toruń). Openair museums in the Silesian voivodeship also boast $19^{\text {th }}$ century mills. A mill from Imielin was moved to the Upper Silesian Ethnographic Park in Chorzów and the Open Air Museum - Croft of the Region of Pszczyna has a mill from Bojszowy. There are also museums that are entirely devoted to mills and the milling industry, e.g. the Jaracz Museum of Milling and Rural Hydraulic Structures, which has operated since 1981 on the site of the former mill hamlet on the Wełna River and has exhibitions on milling techniques and the history of traditional grain processing, and the Pilica River Open-Air Museum in Tomaszów Mazowiecki established in 2000, which has an extensive exhibition devoted to water milling in a wooden watermill. There are an increasing number of local initiatives aimed at the protection of old mills. Since 2010, in a historic steam mill in 
Ustrzyki Dolne, the Museum of Milling and Village Life has operated where visitors learn about the history of milling and can also observe the cereal milling process.

There are also valuable initiatives in the Silesian voivodeship aimed at the preservation and promotion of extant watermills. Such measures include the adaptation of a historic $19^{\text {th }}$ century mill in Żarki for the purposes of the milling and craft museum being established there, which is scheduled to open in 2014. In some cases, old mills are helped by nature. The mill in Pierściec near Skoczów, where lesser horseshoe bats live in summer months, has been recognised as a Natura 2000 special area of conservation.

\subsection{Watermills as tourist attractions}

One of the strategic cultural development objectives in the Silesian voivodeship is the preservation and promotion of the cultural heritage (including post-industrial heritage) of the region and making better use of this heritage for tourism purposes (STRATEGIA ROZWOJU KULTURY; WALKER ET AL., 2014). The functions of former industrial plants change - they are either converted into cultural, leisure and service centres or residential buildings or become post-industrial tourist attractions.

There are still numerous old, mostly disused watermills on the rivers of the Silesian voivodeship that may be of interest not only to those passionate about the history of technology but also to tourists who wish to explore their own region. One way to protect mills and restore them is through promoting various activities, including tourism. Unfortunately, for economic or ownership reasons, it is not feasible to maintain all extant mills.

Measures are being implemented in order to promote the watermill legacy. In many regions of Poland, themed watermill tourist routes are being created, e.g. the Mills of the Szreniawa River Valley bike trail near Kraków, the River Bystra watermill trail in the Lublin region and the River Grabia and River Mroga watermill trails in the Łódź region. Tourists interested in the history of technology appreciate watermills that have remained in situ owing to their authenticity within the surrounding landscape.

Tourist routes in the Silesian voivodeship also include watermills, e.g. the Szwajcaria Zagłębiowska Route incorporates the watermill on the River Biała Przemsza in Dąbrowa Górnicza-Okradzionów (currently operating as a small hydro power plant), which will also be included in the Dąbrowa Basin local industrial monument route that is now being established. The historic mill in Dąbrowa Górnicza-Ratanice is in a bad state of disrepair and all that has been preserved from the Szałas watermill in Dąbrowa Górnicza-Strzemieszyce are ruins of structures and remains of the mill pond and race. An interesting tourist site is the Kołaczew watermill in Złoty Potok (included in the Wooden Architecture Route of the Silesian voivodeship), which dates from the early $19^{\text {th }}$ century. A site of historic, landscape and natural value, which may be an attractive stop on an industrial tourism route, is the mill race in Cieszyn with a historic watermill together with the accompanying hydro-engineering structures (adapted to serve as a textile factory floor) and the disused hydro power plant above it.

In the Silesian voivodeship, there are many watermills that deserve attention; some of those are listed in the register of monuments maintained by the National Heritage Board of Poland. Unfortunately, most disused mills are falling into disrepair and are slowly disappearing; only a few have been preserved in good condition. Examples that should be mentioned here include watermills on the River Liswarta, e.g. in Kuźnica Nowa, in Krzepice (Fig. 3), in Troniny (Fig. 4), in Krym (Fig. 5), and on the River Pilica and its tributaries (e.g. in Biała Wielka and Bogumiłek). Many of these have long histories and they are also situated in areas attractive to tourists.

A good way to make rational use of historic post-industrial sites, while preserving them from devastation, is to adapt them for other purposes, e.g. recreational, commercial or residential ones. With funds, e.g. from the European Regional Development Fund, the function of the mill can be changed and it can be made available to tourists. Mills are converted into restaurants and hotels and adapted for residential purposes or to serve as public buildings. In the valley of the River Schlaube in Germany there is the "Imperial Old Mill Route" where historic mills have been restored and are now used as restaurants or hotels. Similar facilities operate in Poland, e.g. in Lower Silesia and Pomerania. In the analysed area of the Silesian voivodeship, the mill in ŁugiRadły on the River Liswarta has been turned into a granary, and the owner of the mill runs an agritourism farm nearby. In the case of watermills, which are mostly found in rural areas, not all such conversions are practicable. More possibilities can be identified for mills situated in cities. An example of this is the historic watermill 
on the Radunia Canal in Gdańsk, which has been converted into a shopping mall. Mills and old dams can also be used to construct small hydro

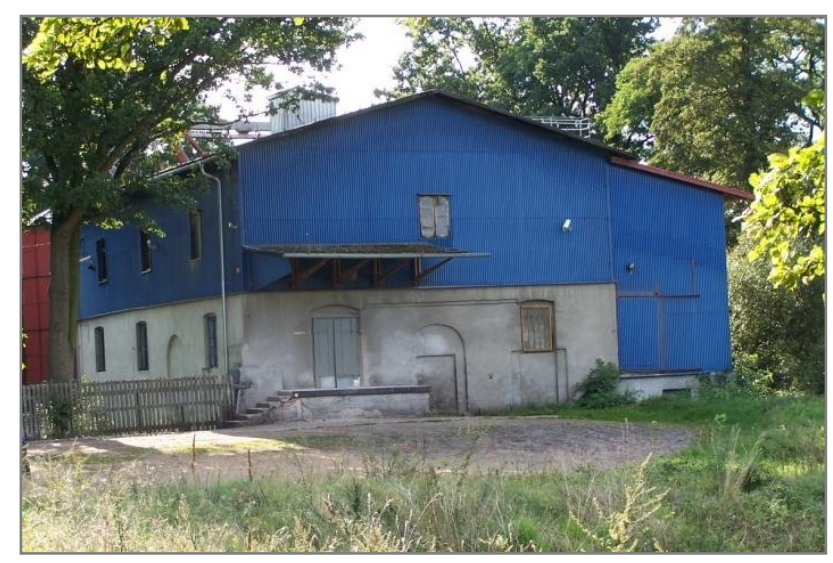

Fig. 2. Historic mill in Kuźnica Stara on the River Pankówka (M. Fajer)

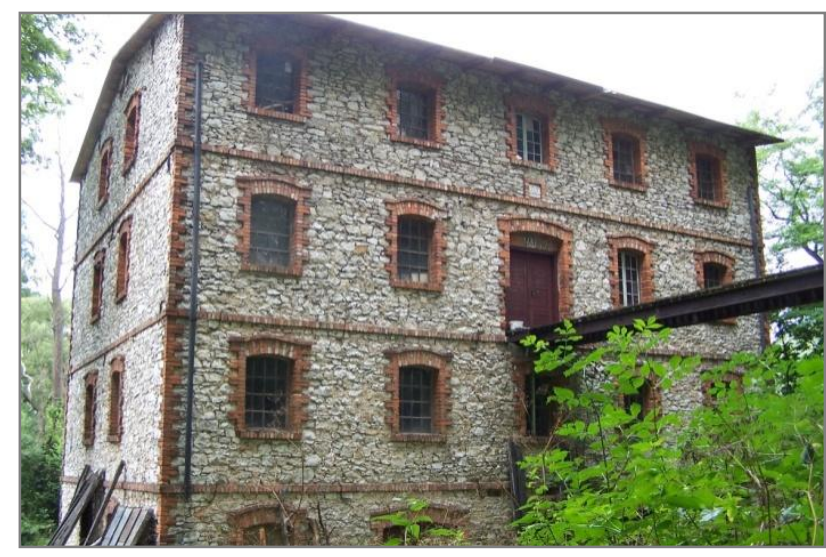

Fig. 4. Mill in Troniny on the River Liswarta (M. Fajer)

\section{Discussion}

Numerous watermills have been preserved in the Silesian voivodeship, but few are registered monuments. In this respect, the achievements of the Silesian voivodeship appear modest, especially in comparison with the Warmia-Mazury, Lower Silesia or Mazovia voivodeships.

No extensive studies on watermills as industrial monuments and their value as tourist attractions have been conducted in the Silesian voivodeship. Ethnographic studies in this area have been conducted for many years by the Upper Silesian Ethnographic Park in Chorzów, which documents selected mills using photographs and videos. This work has resulted e.g. in exhibitions on cereal mills, including an exhibition of photographs of watermills on the Rivers Liswarta and Pankówka. This is a good example of activities that aim not only to provide museum plants. Such plants operate on the River Biała Przemsza in Okradzionów and on the River Liswarta in Rębielice Szlacheckie.

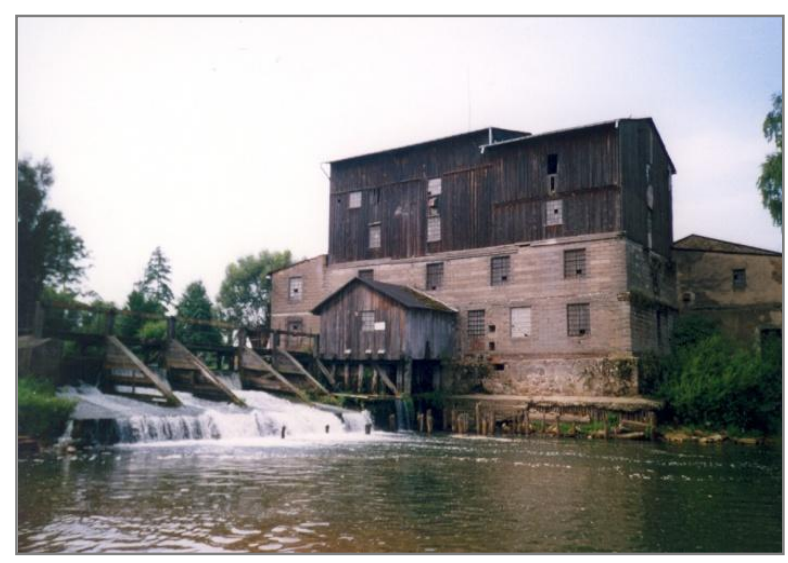

Fig. 3. Marcelin mill in Krzepice (before weir renovation) (M. Fajer)

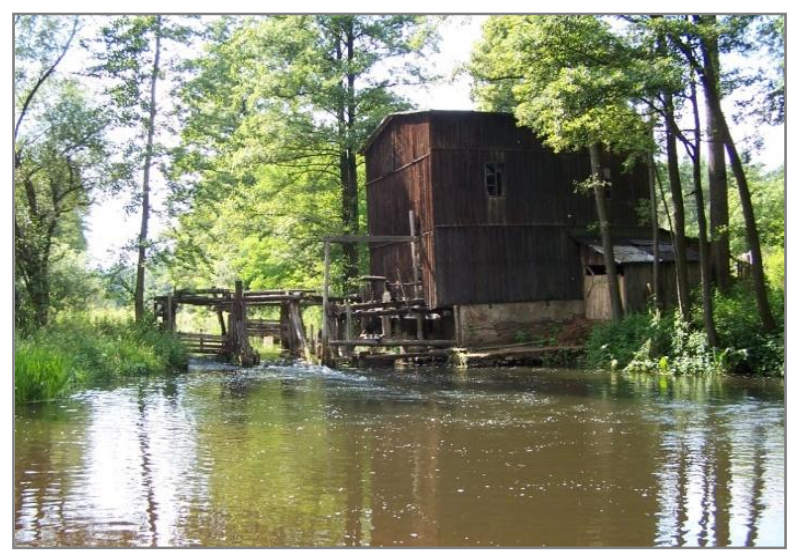

Fig. 5. Krym mill in the lower reach of the River Liswarta (M. Fajer)

material but also to promote the watermill legacy in the Silesian voivodeship.

The problem of watermills that are falling into disrepair is present not only in Silesia - it also of concern to other regions of Poland and Europe as well. Authors who have examined mills in the Podlasie and Eastern Mazovia regions (BALIŃSKA \& BALIŃSKI, 2003) call for the protection of not just the watermills themselves and their equipment, but also of the entire mill farmsteads as well as of the systems used to dam water.

Studies concerning the importance of watermills for tourism conducted in Lithuania have yielded interesting results (STANKEVIČIŪTĖ \& ŽUROMSKAITÉ, 2012). Only 24 watermills are extant in Lithuania and their condition is similar to those in Poland. Lithuanians have also taken various measures in order to preserve those mills. The need to protect them and to use them for tourist purposes has been stressed. The research conducted in Lithuania has demonstrated that the 
original historic structures with equipment preserved inside are the most popular among tourists. Important factors in attracting tourists to watermills are catering services, the possibility to sleep in a historic building and easy access.

In the case of watermills, cultural parks are a good way of protecting them and converting them for tourism purposes; this is exemplified by the "Three Mill Valley" in Bogdaniec (LIPIŃSKA, 2011). Some mills in the Silesian voivodeship could benefit from such protection, which covers mill structures together with dams and parts of the valley.

\section{Conclusion}

Watermills are an increasingly rare feature in the landscape of river valleys in the Silesian voivodeship, just as in the rest of Poland. Most surviving mills are wooden or brick and wood structures characteristic of $19^{\text {th }}$ and early $20^{\text {th }}$ century mill architecture. The condition of extant mills varies. Mills that still operate and provide services to the public are rare in rural areas.

Just six watermills from the Silesian voivodeship are listed in the register of monuments of the National Heritage Board of Poland. Today, watermills should be regarded as technological and milling industry monuments. There is no doubt that watermills should be preserved. The inclusion in open-air museums is not the only solution - any form of protection in situ through putting them to different uses is also valuable. Changing the function of a mill to serve as a hotel, restaurant, cultural centre, etc. makes it possible to maintain these sites as parts of river valley landscape.

\section{References}

Balińska G., Baliński J.A. 2003. Młyny ziemi łomżyńskiej. Oficyna Wyd. Polit. Wrocławskiej. Wrocław.

Baranowski B. 1977. Polskie młynarstwo. Zakł. Nar. im. Ossolińskich - Wyd., Wrocław.

Bartyś J. 1978. Stan i potrzeby badań nad historią techniki przemysłu spożywczego w Polsce. Kwart. Historii Nauki i Techniki, 23/1: 135-156.

Burzyński T., Łabaj M. (eds.) 2005. Dziedzictwo przemysłowe jako atrakcyjny produkt dla turystyki i rekreacji. Doświadczenia krajowe i zagraniczne. Mat. II Międzynar. Konf. Nauk.-Prakt., Górnośl., Zabrze 2005. Wyż. Szk. Handl. im. Wojciecha Korfantego, Urz. Miej. w Zabrzu. Katowice.

Burzyński T., Staszewska-Ludwiczak A., Pasko K. (eds.) 2009. Dziedzictwo przemysłowe jako element zrównoważonego rozwoju turystyki. Mat. II Międzynar. Konf. Nauk.-Prakt., Zabrze 2008. Górnośl. Wyż. Szk. Handl. im. Wojciecha Korfantego, Urz. Miej. w Zabrzu. Katowice.
Fajer M. 2011. Antropogeniczne przeobrażenia den dolin rzecznych na Wyżynie Woźnicko-Wieluńskiej w XVIII-XX w. [in:] Zieliński A. (ed.) Znane fakty - nowe interpretacje $w$ geologii i geomorfologii. Uniw. Jana Kochanowskiego, Inst. Geogr., Kielce: 9-22.

Fajer M., Waga J.M. 2010. Uwarunkowania lokalizacji siłowni wodnych na Liswarcie. Kształt. środ. geogr. i ochr. przyr. na obsz. uprzem. i zurban., 41: 19-21.

Kaniecki A., Brychcy D. 2010. Średniowieczne młyny wodne i ich wpływ na przemiany stosunków wodnych na przykładzie zlewni Obry Skwierzyńskiej. Bad. Fizjogr., R. I, Seria A, Geografia Fizyczna (A61): 145-156.

Kuźnicki T. 2009. Z dziejów młynarstwa Radomska i regionu (Katalog). Tow. Opieki nad Zabytkami, Oddz. w Radomsku. Radomsko.

Lamparska M. 2013. Post-industrial Cultural Heritage Sites in the Katowice conurbation, Poland. Environ. \& Socioecon. Stud., 1, 2: 36-42.

Lipińska I. 2011. Turystyka dziedzictwa kulturowego - wybrane aspekty ochrony prawnej parku kulturowego. Turystyka Kulturowa, 3: 14-27. www.turystykakulturowa.org (20.09.2014).

Osiecki B. 2005. Uwagi do definicji turystyka w obiektach przemysłowych. [in:] Burzyński T. (ed.). Dziedzictwo przemysłowe jako atrakcyjny produkt dla turystyki $i$ rekreacji. Doświadczenia krajowe $i$ zagraniczne. Min. Gosp. i Pracy, Górnośl. Wyż. Szk. Hand., Urz. Miej. w Zabrzu, Zabrze: 309-312.

Paszkiewicz A. E. 2005. Ochrona dziedzictwa przemysłowego. Kwart. Historii Nauki i Techniki, 50/2: 308-320.

Podgórski Z. 2001. Wpływ budowy młynów wodnych na zmiany krajobrazów Pojezierza Chełmińskiego. Krajobraz kulturowy. Idee, problemy, wyzwania. MygaPiątek U. (ed.), Prace Wydz. Nauk o Ziemi UŚ, 12: 117122.

Podgórski Z. 2004. Wpływ budowy i funkcjonowania młynów wodnych na rzeźbę terenu $i$ wody powierzchniowe Pojezierza Chełmińskiego i przyległych części dolin Wisły $i$ Drwęcy. UMK, Toruń.

Podgórski Z. 2009. Młyny wodne w krajobrazie Pojezierza Chełmińskiego. Prace i Stud. Geogr., 41: 151-161.

Rejestr zabytków województwa śląskiego. Narod. Inst. Dziedz. http://www.nid.pl/pl/Informacje_ogolne/Zabytki_w_Pol sce/Ewidencja_zabytkow/ (20.09.2014).

Słownik historyczno - geograficzny ziem polskich w średniowieczu. Ed. elektron. Jurek T. (ed.). Inst. Hist. Pol. Akad. Nauk. http://www.slownik.ihpan.edu.pl/index.php (20.09.2014).

Stankevičiūtė D., Žuromskaitė B. 2012. Rola młynów i wiatraków drewnianych $\mathrm{w}$ rozwoju turystyki dziedzictwa kulturowego na Litwie. Turystyka Kulturowa, 7: 45-60. www.turystykakulturowa.org (20.09.2014).

Strategia rozwoju kultury $\mathrm{w}$ województwie śląskim na lata 2006-2020 http://www.slaskie.pl/ (20.09.2014).

Walker M., Caban E., Cholewa D., Goniewicz A., Kontny I., Syska A., Woźniakowska A. 2014. Wojewódzki program opieki nad zabytkami $w$ województwie śląskim na lata 2014-2017. Śl. Centrum Dziedz. Kult. w Katowicach.

Ziętara B. 1954. Dzieje małopolskiego hutnictwa żelaznego $X I V$-XVII w. PWN, Warszawa.

http://www.nid.pl

http://www.polskaniezwykla.pl

http://skansen.chorzow.pl

http://skanseny.net

http://www.zabytkitechniki.pl 